\title{
ПОДАТКОВА БЕЗПЕКА УКРАЇНИ В УМОВАХ НОВИХ ФІНАНСОВО-ЕКОНОМІЧНИХ ВИКЛИКІВ
}

\section{Коломієць П. В.}

\section{Вступ}

Актуальність теми дослідження податкової безпеки України в умовах сучасних фінансово-економічних викликів зумовлена реаліями сьогодення, перед якими країна постала. Серед загроз податковій безпеці, що ускладнюють реалізацію національних інтересів України у сфері оподаткування, не останнє місце займають дискреційні повноваження органів влади як чинники корупції.

Метою нашого дослідження $є$ огляд проблематики делегування законодавчою владою дискреційних повноважень податковим органам та 3'ясування ролі дискреції (розсуду) в податковому законодавстві України. Не менш важливим питанням, що розглядається в цій статті, $є$ відповідність наявної в податковому законодавстві України дискреції головному принципу права - принципу верховенства права. Окремим завданням дослідження є вивчення поглядів науковців стосовно правових обмежень, які можуть запобігти зловживанню дискреційними повноваженнями в податковій царині.

Виконання основного завдання дослідження - наукового пізнання податкової безпеки України в умовах сучасних фінансово-економічних викликів забезпечено системою методів, сформованих на основі сучасних реалій суспільних відносин у сфері податкової безпеки. Використання діалектичного методу пізнання суспільних відносин, що виникають у сфері податкової безпеки, дало змогу об'єктивно оцінити дійсний стан загроз податковій безпеці, що ускладнюють реалізацію національних інтересів України у сфері оподаткування, не останнє місце серед яких належить дискреційним повноваженням податкових органів влади як чинникам корупції. Системний метод дав змогу відібрати із загального масиву податкового законодавства України та систематизувати нормативні акти, що прямо чи опосередковано стосуються дискреційних повноважень податкових органів влади. На основі результатів теоретичного методу аналізу нормативно-правових актів органів влади у сфері податкової безпеки в Україні простежено процес формування дискреційних повноважень у податковому законодавстві. Застосування формальноправового методу забезпечило змогу отримати достовірні результати 
наукового пошуку шляхом опису, класифікації й систематизації, формулювання, пояснення, аргументації i критики визначення понять нормативно-правових актів у сфері щодо дискреційних повноважень.

\section{1. Щодо поняття дискреційних повноважень}

Небагато аспектів законодавства про доходи породжують сильніші почуття, ніж здійснення дискреційної влади з боку податкової служби .

Дискреція (лат. discretio) - розв'язання службовою особою або державним органом якогось питання на власний розсуд².

Насамперед, звернемо увагу на етимологію терміна «дискреція». Здебільшого походження цього терміна пов'язують із латинським словом discretion, що означає «розподіл», чи французьким еквівалентом discretionnarie - «залежний від власного розсуду». Попри те, на наше глибоке переконання, найбільш повно зрозуміти природу та сучасне значення дискреції можна, звернувшись до англомовного варіанта цього терміна: «Discretion - 1) свобода розсуду; 2) здоровий глузд». Тому, на наш погляд, дискреція передбачає одразу дві складові частини - вольову, яка включає вільний розсуд, і інтелектуальну (морально-правову), яка означає використання дискреційних повноважень «за здоровим глуздом». Своєрідним компенсатором цього «здорового глузду» в європейських країнах є конституційні традиції та звичаї, які не дозволяють посадовій особі в процесі реалізації дискреційних повноважень спиратись виключно на внутрішню мотивацію. Загалом ефективно інститут дискреційних повноважень може існувати за наявності одразу таких трьох явищ конституційної відповідальності вищих органів влади за прийняті ними рішення, довіри між інституціями влади, втрата якої веде до зміни персонального складу цих інституцій, та стійких конституційних традицій ${ }^{3}$.

Тема «дискреційних повноважень» є актуальною і нині. Підтвердженням тому $\epsilon$ наукова робота А.А. Гріня «Дискреційні повноваження органів виконавчої влади України та їх реалізація», в якій автор пропонує визначення поняття дискреційних повноважень як сукупності прав i обов'язків, закріплених адміністративним законодавством, для реалізації покладених на орган виконавчої влади чи його посадову особу функцій, що надають йому певний ступінь свободи розсуду оцінювати ситуації, здійснювати правомірний вибір між законними альтернативами та не

\footnotetext{
${ }^{1}$ Cogan D. The Delicate Balance: Tax, Discretion and the Rule of Law / C. Evans, Ju. Freedman, R. Krever (eds.). Amsterdam : IBFD, 2011. P. 1.

2 Мельничук О.С. Словник іншомовних слів. Київ: Головна редакція української радянської енциклопедії, 1985. С. 261.

3 Барабаш Ю.Г. Дискреційні повноваження вищих органів влади: правова природа та умови ефективного застосування. Університетські наукові записки. 2007. № 4. С. 49-54.
} 
передбачають обов'язків узгоджувати свої рішення (дії) з будь-яким іншим суб'єктом ${ }^{4}$.

Н.О. Ханова в дисертаційній роботі «Дискреційні повноваження контролюючих органів у сфері оподаткування в Україні», підсумовуючи результати дослідження, зазначає, що функції контролюючих органів можуть бути класифіковані за низкою критеріїв: контрольна, сервісна, організаційно-установча, інформаційно-аналітична, представництва інтересів, охоронна та ін. Увагу авторка концентрує на тому, що контрольна функція суб'єктів владних повноважень є головною5. Н.О. Ханова стверджує: «Детермінація правової природи обов'язків контролюючих органів дозволила виокремити активні й пасивні обов'язки. Під активними обов'язками потрібно розуміти зобов'язання, пов'язані з учиненням контролюючим органом активних дій. Пасивні обов'язки полягають в необхідності утриматися від учинення тих чи інших дій. Фактично їх можна назвати «обов'язки з бездіяльності», де останнє виявляється в недопущенні дій, які порушували б ті чи інші вимоги чинного законодавства, могли б призвести до порушення прав та інтересів учасників суспільних відносин. Правова терміносполука «дискреційні повноваження» містить у собі логічну помилку, а саме: термін «повноваження» об'єднує такі складники, як права й обов'язки (у формульному вираженні: повноваження $=$ права + обов'язки). Але ж обов'язок здійснити розсуд не $\epsilon$ сумісним із правовою природою розглядуваного поняття, тобто здійснення дискреції не може бути поставлено в обов'язок органу державної влади. Не $\epsilon$ обов'язком реалізація дискреційних повноважень і для контролюючих органів. Отже, застосування розсуду є правом суб'єкта, що аж ніяк не стосується другого складника поняття «повноваження» - обов'язків. Ось чому більш доцільно вести мову про категорію «дискреційні права», а не про «дискреційні повноваження» або ж окреслювати умовність використання поняття «повноваження» в цій правовій конструкції. За відповідного підходу термін «повноваження» розглядається в його утятому, скороченому виді з урахуванням такого його складника, як права; при цьому нехтується такий його елемент, як обов'язки. Наведене не заперечує змоги оперувати категорією «дискреційні повноваження» як усталеним поняттям»

\footnotetext{
${ }^{4}$ Грінь А.А. Дискреційні повноваження органів виконавчої влади України та їх реалізація : дис. ... канд. юрид. наук. Київ, 2019. С. 201-202.

${ }^{5}$ Ханова Н.О. Дискреційні повноваження контролюючих органів у сфері оподаткування в Україні : дис. ... канд. юрид. наук. Дніпро, 2019. С. 169.

6 Ханова Н.О. Дискреційні повноваження контролюючих органів у сфері оподаткування в Україні : дис. ... канд. юрид. наук. Дніпро, 2019. С. 170-171.
} 
І.Л. Желтобрюх, дослідивши у дисертаційній роботі розсуд у податковому правозастосуванні, встановила, що дискреційні повноваження - це повноваження, які контролюючий орган, що приймає рішення, може здійснювати з певною свободою розсуду, а саме коли такий орган може обирати з кількох юридично допустимих рішень те, яке він вважає найкращим за цих обставин ${ }^{7}$. Водночас вчена зазначає, що, на перший погляд, податкове право не можна охарактеризувати як галузь права, в якій допустиме застосування такого поняття, як розсуд. На користь такої позиції першочергово говорить імперативність усієї галузі податкових відносин, чітка регламентація усіх процесів та процедур, домінування обов'язків над правами. Але така урегульованість податкових відносин іноді призводить до розширення компетенції контролюючих органів, виникнення дискреційних повноважень, що своєю чергою $\epsilon$ однією $з$ підстав для негативного розсуду таких органів. ${ }^{8}$

Ю.Г. Барабаш у статті «Дискреційні повноваження вищих органів влади: правова природа та умови ефективного застосування» наголошує, що поступово з поля зору конституціоналістів зникає «дискреційний» характер цілої низки ключових повноважень вищих органів влади, а якщо точніше, то - ставлення до таких повноважень як до «дискреційних». Попри те, події, що відбуваються в українському політикумі останнім часом, дають змогу говорити про необхідність внесення «на порядок денний» сучасної науки конституційного права проблематики дискреційних повноважень. Підсумовуючи результати дослідження, науковець констатує: «1. Ефективність використання інституту дискреційних повноважень у конституційноправовому регулюванні ми пов'язуємо 3 наявністю трьох ключових державно-правових явищ: конституційної відповідальності вищих органів влади за прийняті ними рішення; довіри між інституціями влади, втрата якої веде до зміни персонального складу цих інституцій, та стійких конституційних традицій. Разом із тим, як це не дивно, застосування дискреції на конституційному рівні в перехідних умовах розвитку державності може в окремих випадках сприяти ефективному функціонуванню органів влади, конструктивному вирішенню державноправових конфліктів та виробленню вищеназваних традицій. Хоча звичне використання цього інструменту має бути досить виваженим. 2. Надмірна «захопленість» процесуально-процедурною стороною врегулювання діяльності вищих органів влади на конституційному рівні може призвести і призводить до поступового витіснення політики як сфери, де діє розсуд i

\footnotetext{
7 Желтобрюх І.Л. Розсуд в податковому правозастосуванні : дис. ... канд. юрид. наук. Ірпінь, 2016. C. 173.

8 Желтобрюх І.Л. Розсуд в податковому правозастосуванні : дис. ... канд. юрид. наук. Ірпінь, 2016. C. 3 .
} 
вибір форм і методів прийняття рішень із діяльності вищих посадовців. 3. Дискреція в окремих випадках залишилась лише формальною стороною прийняття вищими посадовцями важливих державних рішень. Простіше кажучи, незважаючи на конституційне закріплення, та чи інша посадова особа практично позбавлена змоги приймати рішення «за власним розсудом», адже іії рішення вже передбачено діями іншого посадовця, який виступив його ініціатором»

У науковому висновку за результатами дослідження щодо меж дискреційного повноваження суб'єкта владних повноважень та судового контролю за його реалізацією, що було здійснено за дорученням Голови Касаційного адміністративного суду у складі Верховного Суду, стверджується, що на роль доктринальних можуть претендувати такі теоретичні положення: 1) дискреційне повноваження може полягати у виборі діяти, чи бездіяти, а якщо діяти, то у виборі варіанту рішення чи дії серед варіантів, що прямо або опосередковано закріплені в законі. Важливою ознакою такого вибору $\epsilon$ те, що він здійснюється без необхідності узгодження варіанту вибору 3 будь-ким; 2) дискреційне повноваження надається у спосіб його закріплення в оціночному понятті, відносно визначеній нормі, альтернативній нормі, нормі із невизначеною гіпотезою. Для позначення дискреційного повноваження законодавець використовує, зокрема, терміни «може», «має право», «за власної ініціативи», «дбає», «забезпечує», «веде діяльність», «встановлює», «визначає», «на свій розсуд». Однак наявність такого терміна в законі не свідчить автоматично про наявність у суб'єкта владних повноважень дискреційного повноваження; такий термін $є$ приводом для докладного аналізу закону на предмет того, що відповідне повноваження $є$ дійсно дискреційним; 3) в процесі реалізації дискреційного повноваження суб'єкт владних повноважень зобов'язаний поважати основоположні права особи, додержуватися конституційних принципів, принципів реалізації відповідної владної управлінської функції, принципів здійснення дискреційних повноважень, змісту публічного інтересу, положень власної компетенції, вказівок, викладених у інтерпретаційних актах, фахових правил, закріплених у нормативних актах, адміністративної практики, судової практики, процедурних вимог; 4) критеріями судового контролю за реалізацією дискреційних повноважень є: критерії перевірки діяльності публічної адміністрації, встановлені Кодексом адміністративного судочинства України, зокрема, мета, з якою дискреційне повноваження надано, об'єктивність дослідження доказів у справі, принцип рівності перед

\footnotetext{
9 Барабаш Ю.Г. Дискреційні повноваження вищих органів влади: правова природа та умови ефективного застосування. Університетські наукові записки. 2007. № 4. С. 49-54.
} 
законом, безсторонність; публічний інтерес, задля якого дискреційне повноваження реалізується; зміст конституційних прав та свобод особи; якість викладення в дискреційному рішенні доводів, мотивів його прийняття ${ }^{10}$.

На думку О.О. Гайдуліна, запровадження широкої дискреції, з огляду на євроінтеграційні процеси, є неприйнятним в українських реаліях. Поняття правового регулювання та дискреції контрарні (протилежні), але не контрадикторні (не виключають одне одного). Законодавче регулювання істотно доповнюється саморегулюванням, яке неможливе без наділення суб'єктів правореалізації дискреційними повноваженнями, суть яких полягає в автономії нормотворчого волевиявлення ${ }^{11}$.

Дискреційні повноваження - це сукупність прав та обов'язків органів державної влади та місцевого самоврядування, осіб, уповноважених на виконання функцій держави або місцевого самоврядування, що дають змогу на власний розсуд визначити повністю або частково вид і зміст управлінського рішення, яке приймається, або вибрати на власний розсуд один із кількох варіантів управлінських рішень, передбачених нормативноправовим актом, проєктом нормативно-правового акта (п. 1.6 Методології проведення антикорупційної експертизи № 1395/5) ${ }^{12}$.

\section{2. Погляди науковців стосовно дискреційних повноважень органів влади як чинника корупції, що є загрозою податковій безпеці}

Частково окреслена тема вже мала місце в роботах сучасних дослідників: О.А. Білик, незважаючи на відсутність конкретних робіт, в яких би вивчалася проблематика дискреційного характеру податкової системи в українському селі першої половини 1920-х років, виявив науковий інтерес до окресленої теми та, дослідивши ii, зазначив, що протягом першої половини 20-х років XX ст. була встановлена нова, але мало чим відмінна в методах та формах стягнень податкова система, яка мала дискреційний характер. «А отже селяни продовжували перебувати у фактичній залежності від держави» ${ }^{13}$.

\footnotetext{
${ }^{10}$ Науковий висновок щодо меж дискреційного повноваження суб'єкта владних повноважень та судового контролю за його реалізацією. URL: https://supreme.court.gov.ua/supreme/pro_sud/ naukovi_visnovki/nauk_visnovok_01_03_2018. (дата звернення: 27.05.2020).

11 Гайдулін О.О. Компаративна інтерпретація понять законодавчого регулювання та правової дискреції: досвід Казахстану та перспективи для України. Часопис Київського університету права. 2018. № 3. С. 26-29.

12 Про затвердження Методології проведення антикорупційної експертизи : Наказ Міністерства юстиції України від 24.04.2017 р. № 1395/5. URL: https://zakon.rada.gov.ua/laws/show/v1395323-17. (дата звернення: 24.05.2020).

${ }^{13}$ Білик О.А. Дискреційний характер податкової системи в українському селі першої половини 1920-х pp. Украӥнський селянин. 2012. Вип. 13. С. 174-177.
} 
Л.М. Бєлкін, фрагментарно розглянувши дискреційні повноваження податкових органів влади як чинника корупції, зауважує, що недотримання принципу обмеження дискреційних повноважень і привласнення таких повноважень органами та/або особою, уповноваженою на виконання функцій держави або місцевого самоврядування, створює підгрунтя для корупції. 3 огляду на високий рівень корумпованості чиновників в Україні, перевагу варто надавати обмеженням дискреційних повноважень, аніж їх наданню ${ }^{14}$.

М.К. Золотарьова в науковому дослідженні «Щодо окремих питань застосування дискреційних повноважень посадовими особами органів Державної фіскальної служби України» наголошує, що на тлі кризових явищ, які мають місце у вітчизняній економіці, для держави особливої гостроти набуває питання мобілізації податкових надходжень до бюджету, що не можна вирішити без ефективного здійснення податкового контролю. Нині перевага в державній податковій політиці надається саме фіскальній функції, що призводить до надмірного податкового тиску та адміністративного контролю з боку уповноважених органів. Це положення повною мірою стосується контрольно-перевірочної роботи, тобто сфери податкового контролю. А отже, надані органам Державної фіскальної служби України дискреційні повноваження перетворюються на небезпечний інструмент, що унеможливлює побудову ними партнерських відносин із платниками податків і є підставою для свавілля та посилення корупції в податкових відносинах ${ }^{15}$.

Д.А. Кобильнік переконаний, що дискреційні повноваження мають бути в органів, що провадять діяльність із мобілізації, розподілу та використання коштів публічних фондів. Науковець згоден із тим, що їх існування - «це найкращій вияв правової держави». Надання владним суб'єктам таких повноважень дасть змогу ефективніше провадити фінансову діяльність, оскільки передбачає змогу прийняти оптимальне для конкретного випадку рішення. Однак їх встановлення обов'язково передбачає визначення на законодавчому рівні меж, в яких мають діяти владні учасники правовідносин ${ }^{16}$.

Як стверджує О.В. Костяна, нині в податковому регулюванні в Україні переважає застосування заходів дискретного характеру, що полягає в

\footnotetext{
14 Бєлкін Л.М. Дискреційні повноваження органів влади як чинник корупції. Боротьба $з$ організованою злочинністю і корупцією (теорія і практика). 2011. Вип. 24. С. 91-100.

15 Золотарьова М.К. Щодо окремих питань застосування дискреційних повноважень посадовими особами органів Державної фіскальної служби України. Форум права. 2015. № 1. С. 123-128.

16 Кобильнік Д.А. Деякі міркування стосовно дискреційних повноважень органів, що здійснюють фінансову діяльність в Україні. Теорія $i$ практика правознавства. 2015. Вип. 2. URL: http://nbuv.gov.ua/UJRN/tipp_2015_2_20. (дата звернення: 27.05.2020).
} 
цілеспрямованому маневруванні величиною податкових надходжень до бюджету внаслідок додаткових дій із боку уряду, пов'язаних із розробкою та ухваленням нових норм та правил стягнення податків відповідно до поточних цілей та завдань державної економічної політики ${ }^{17}$. Вчена вважає, що зазвичай зміни в правилах оподаткування, які $є$ наслідком здійснення дискреційної податкової політики, впроваджуються задля певного впливу на бази оподаткування. Тому необхідним є детальний аналіз результатів застосування заходів дискреційної податкової політики, що вже мали місце в нашій державі ${ }^{18}$.

Розсуд у податково-правовому регулюванні, за твердженням М.П. Кучерявенка, - доволі складне і багатоаспектне явище. Незважаючи на застосування імперативного методу правового регулювання податкових відносин, певні суб'єкти відповідно до норм податкового законодавства мають змогу реалізовувати повноваження не в чіткій відповідності до законодавчого припису, а обираючи один із кількох можливих варіантів поведінки. Такий розсуд має загальні ознаки, що притаманні розсуду як загальноправовому поняттю, і особливі властивості, зумовлені специфікою податкових правовідносин, у динаміці яких він реалізується. Так, особливостями розсуду в податково-правовому регулюванні є: предмет оцінювання; наявність множинності варіантів рішень, кожен 3 яких $\epsilon$ законним; особливий процесуальний порядок; межі, способи, умови делегування окремих аспектів у реалізації певних повноважень учасникам відносин; вибір суб'єктом відповідного варіанту поведінки під час реалізації його прав. Основними факторами, що зумовлюють існування кількох варіантів поведінки суб'єктів податкових правовідносин, $\epsilon$ характер i зміст податково-правових норм, специфіка термінології податкового законодавства, наявність колізій податково-правових норм i оціночних понять у змісті останніх ${ }^{19}$.

\section{3. Дискреційні повноваження як корупційні ризики в діяльності органів державного управління}

Як відомо, корупція є однією з найнебезпечніших загроз правам людини, демократії, правопорядку, чесності та соціальній справедливості, вона перешкоджає економічному розвитку та загрожує належному i справедливому функціонуванню країн, має негативні фінансові наслідки для

\footnotetext{
17 Костяна О.В. Роль інструментів дискреційного та недискреційного податкового регулювання у стабілізації циклічних коливань економічного розвитку. Економічний аналіз. 2014. Т. 15(2). С. 57-63.

18 Костяна О.В. Аналіз впливу заходів дискреційної податкової політики на бази оподаткування прямих податків. Бізнес Інформ. 2012. № 7. С. 141-145.

${ }^{19}$ Кучерявенко М.П. Особливості розсуду в податково-правовому регулюванні. ScienceRise. Juridical Science. 2017. № 1. С. 37-41.
} 
громадян, компаній і держав, а також для міжнародних установ. Нині в нашій державі здійснюється низка заходів у сфері запобігання та протидії корупції, більшість спрямована саме на запобігання корупції, як i в більшості країн Європи. Одним з основних напрямів у сфері запобігання корупції $\epsilon$ виявлення корупційних ризиків, які можуть виникнути в діяльності державних службовців, а також усунення умов та причин виникнення цих ризиків. Вказані корупційні ризики постійно досліджуються науковцями та громадськими організаціями в різних сферах державного управління. При цьому за поширеністю корупційні ризики в діяльності державних службовців можна розташувати в такому порядку: недоброчесність державних службовців; виникнення конфлікту інтересів; безконтрольність із боку керівництва; наявність дискреційних повноважень. У переліку корупційних ризиків $\epsilon$ наявність дискреційних повноважень, оскільки саме наявність змоги діяти на власний розсуд створює умови для вчинення корупційних правопорушень. Дискреційні повноваження мають низку загальних ознак, а саме: 1) дозволяють органу (особі, уповноваженій на виконання функцій держави) на власний розсуд оцінювати юридичний факт (фактичний склад), внаслідок чого можуть виникати, змінюватись або припинятись правовідносини; 2) дають змогу на власний розсуд обирати одну з кількох запропонованих у проекті нормативно-правового акта форм реагування на цей юридичний факт; 3) дають змогу органу (особі, уповноваженій на виконання функцій держави) на власний розсуд вибирати захід публічно-правового впливу щодо фізичних та юридичних осіб, його вид, розмір, спосіб реалізації; 4) дають змогу органу (особі, уповноваженій на виконання функцій держави) вибрати форму реалізації своїх повноважень - видання нормативного або індивідуально-правового акта, вчинення (утримання від вчинення) адміністративної дії; 5) наділяють орган (особу, уповноважену на виконання функцій держави) правом повністю або частково визначати порядок здійснення юридично значущих дій, у тому числі строк та послідовність їх здійснення; 6) дають змогу органу (особі, уповноваженій на виконання функцій держави) на власний розсуд визначати спосіб виконання управлінського рішення, в тому числі передавати виконання прийнятого рішення підлеглим особам, іншим органам державної влади та місцевого самоврядування, встановлювати строки і процедуру виконання. Проведення антикорупційної експертизи сприяє усуненню корупціогенних факторів ще на етапі нормотворення, що в результаті виключає наявність дискреційних повноважень. Це $є$ дуже важливим та позитивним кроком у сфері запобігання виникнення корупції ${ }^{20}$.

\footnotetext{
${ }^{20}$ Корупційні ризики в діяльності державних службовців : Роз'яснення Міністерства юстиції України від 12.04.2011 p. URL: https://zakon.rada.gov.ua/laws/show/n0026323-11. (дата звернення: 24.05.2020).
} 
Дослідивши дискреційні повноваження як корупційні ризики в діяльності органів державного управління, С.А. Резанов констатує, що застосування дискреційних прав - це дозволена законом інтелектуальновольова діяльність компетентного суб'єкта, змістом якої $є$ здійснення вибору одного 3 кількох варіантів рішення, встановленого правовою нормою, для забезпечення законності, справедливості, доцільності й ефективності адміністративного регулювання 3 метою ухвалення оптимального рішення у справі, максимально повно забезпечуючи досягнення встановлених правом цілей. До основних ознак дискреційних прав, зауважує науковець, можна зарахувати юридичну дозволеність адміністративного розсуду ${ }^{21}$.

Міністерство юстиції України в Роз'ясненні від 21.05.2012 p. «Антикорупційна експертиза як засіб запобігання корупції» зазначає: «Під час антикорупційної експертизи у проектах нормативно-правових актів найбільше було виявлено недоліків техніко-юридичного характеру, які також сприяють вчиненню корупційних правопорушень. Досить часто проекти містили такий корупціогенний фактор, як неналежне визначення функцій, прав, обов'язків органів державної влади та місцевого самоврядування (дискреція), наслідком чого може бути невиправдане встановлення чи надмірне розширення дискреційних повноважень, створення умов для виникнення конфлікту інтересів та можливостей для зловживання наданими їм повноваженнями» 22 .

Метою Методичних рекомендацій Міністерства юстиції України від 16.10.2013 р. «Запобігання і протидія корупції в державних органах та органах місцевого самоврядування» $\epsilon$ ознайомлення працівників державних органів та органів місцевого самоврядування 3 ключовими положеннями запровадженої у 2011 р. системи запобігання і протидії корупції та вимогами щодо доброчесної поведінки осіб, уповноважених на виконання функцій держави або місцевого самоврядування. Пунктом 13 цих Методичних рекомендацій вказано, що важливою складовою частиною діяльності із запобігання корупції в конкретному органі $\epsilon$ виявлення корупційних ризиків у діяльності органу (правових, організаційних та інших факторів та причин, які породжують, заохочують (стимулюють) корупцію), їх повне усунення або мінімізація. Серед таких ризиків, зокрема, наділення посадових осіб дискреційними повноваженнями - сукупністю прав та обов'язків державних органів та

\footnotetext{
21 Резанов С.А. Дискреційні повноваження як корупційні ризики в діяльності органів державного управління. Право і Безпека. 2014. № 3. С. 88-91.

22 Антикорупційна експертиза як засіб запобігання корупції : Роз'яснення Міністерства юстиції України від 21.05.2012 p. URL: https://zakon.rada.gov.ua/laws/show/n0018323-12. (дата звернення: 24.05.2020).
} 
органів місцевого самоврядування, осіб, уповноважених на виконання функцій держави або місцевого самоврядування, що дають змогу на власний розсуд визначити повністю або частково вид $\mathrm{i}$ зміст управлінського рішення, яке приймається, або вибрати на власний розсуд один із кількох варіантів управлінських рішень ${ }^{23}$.

Порядок проведення антикорупційної експертизи, затверджений наказом Міністерства юстиції України від 18.03.2015 р. № 383/5, визначає механізм проведення антикорупційної експертизи нормативно-правових актів та проектів нормативно-правових актів із метою запобігання вчиненню корупційних правопорушень через наявність у законодавстві корупціогенних факторів, що сприяють або можуть сприяти вчиненню корупційних правопорушень. Антикорупційна експертиза проводиться за методологією проведення антикорупційної експертизи, визначеною законодавством. Антикорупційна експертиза чинних нормативно-правових актів здійснюється щодо законів України, актів Президента України та Кабінету Міністрів України в таких сферах: 1) прав та свобод людини i громадянина; 2) повноважень органів державної влади та органів місцевого самоврядування, осіб, уповноважених на виконання функцій держави або місцевого самоврядування; 3) надання адміністративних послуг; 4) розподілу та витрачання коштів державного бюджету та місцевих бюджетів; 5) конкурсних (тендерних) процедур ${ }^{24}$.

Методологією проведення антикорупційної експертизи, що затверджена наказом Міністерства юстиції України від 24.04.2017 р. № 1395/5 (далі Методологія № $1395 / 5)^{25}$, визначаються типові види, критерії та способи оцінки, а також способи виявлення та усунення корупціогенних факторів у нормативно-правових актах та проєктах нормативно-правових актів. Корупціогенним фактором $\epsilon$ неналежне визначення в нормативноправовому акті, проєкті нормативно-правового акта функцій, прав, обов'язків і відповідальності органів державної влади та місцевого самоврядування, осіб, уповноважених на виконання функцій держави або місцевого самоврядування, наслідком чого може бути невиправдане встановлення чи надмірне розширення дискреційних повноважень, створення умов для виникнення потенційного чи реального конфлікту

\footnotetext{
${ }^{23}$ Методичні рекомендації «Запобігання і протидія корупції в державних органах та органах місцевого самоврядування»: Рекомендації Міністерства юстиції України від 16.10 .2013 р. Урядовий кур’є 'є. 2013. № 208.

${ }_{24}$ Деякі питання проведення антикорупційної експертизи : Наказ Міністерства юстиції України від 18.03.2015 p. № 383/5. URL: https://zakon.rada.gov.ua/laws/show/z0303-15\#n7. (дата звернення:24.05.2020).

${ }^{25}$ Про затвердження Методології проведення антикорупційної експертизи : Наказ Міністерства юстиції України від 24.04.2017 р. № 1395/5. URL: https://zakon.rada.gov.ua/laws/show/v1395323-17 (дата звернення:24.05.2020)
} 
інтересів та можливостей для зловживання наданими їм повноваженнями (п. 2.1 Методології № 1395/5).

Правові та організаційні засади функціонування системи запобігання корупції в Україні, зміст та порядок застосування превентивних антикорупційних механізмів, правила щодо усунення наслідків корупційних правопорушень визначаються Законом України «Про запобігання корупції». У п. 1.1 ст. 1 цього Закону вказано, що корупційне правопорушення - це діяння, що містить ознаки корупції, вчинене особою, зазначеною в ч. 1 ст. 3 цього Закону, за яке законом встановлено кримінальну, дисциплінарну та/або цивільно-правову відповідальність; корупція - це використання особою, зазначеною у ч. 1 ст. 3 цього Закону, наданих ій службових повноважень чи пов'язаних із ними можливостей із метою одержання неправомірної вигоди або прийняття такої вигоди чи прийняття обіцянки/пропозиції такої вигоди для себе чи інших осіб або, відповідно, обіцянка/пропозиція чи надання неправомірної вигоди особі, зазначеній у ч. 1 ст. 3 цього Закону, або на іiі вимогу іншим фізичним чи юридичним особам із метою схилити цю особу до протиправного використання наданих їй службових повноважень чи пов'язаних із ними можливостей. До суб'єктів, на яких поширюється дія цього Закону, відповідно до ч. 1 ст. 3, належать, зокрема: «1) особи, уповноважені на виконання функцій держави або місцевого самоврядування: в) державні службовці, посадові особи місцевого самоврядування; е) посадові та службові особи центрального органу виконавчої влади, що реалізує державну податкову політику, i центрального органу виконавчої влади, що реалізує державну митну політику» ${ }^{26}$.

У Стратегії реформування системи державного нагляду (контролю), схваленої розпорядженням Кабінету Міністрів України від 18 грудня 2017 p. № 1020-p, зазначено про необхідність удосконалення системи державного нагляду (контролю) щодо запобігання правопорушенням у сфері господарської діяльності, зокрема в частині здійснення перегляду, систематизації та удосконалення актів законодавства, які визначають повноваження органів державного нагляду (контролю) в окремих сферах господарської діяльності, 3 питань вжиття заходів реагування щодо виявлення порушення в частині обмеження надмірно широких дискреційних повноважень посадових осіб органів державного нагляду (контролю) щодо вжиття заходів реагування під час здійснення державного нагляду (контролю) ${ }^{27}$.

\footnotetext{
${ }^{26}$ Про запобігання корупції : Закон України від 14.10.2014 р. № 1700-VII. Відомості Верховної Ради Украйни. 2014. № 49. Ст. 2056.

27 Про схвалення Стратегії реформування системи державного нагляду (контролю): Розпорядження Кабінету Міністрів України від 18.12.2017 р. № 1020-р. Офіційний вісник Украӥни. 2018. № 16. Ст. 558.
} 


\section{ВИСНОВКИ}

С деякі ситуації, коли урядова дискреція $є$ єдиним справедливим способом вирішення певних питань. Це прийом, який дає змогу уникнути жорсткості письмового статуту, і це засіб, за допомогою якого можна уникнути реальних випадків негараздів. Часто закон не може передбачити всіх ситуацій, які можуть виникнути, і за відсутності міністерського розсуду немає альтернативи виконувати букву закону ${ }^{28}$.

Результати проведеного аналізу поглядів науковців стосовно дискреційних повноважень органів влади як чинника корупції, що $\epsilon$ загрозою податковій безпеці, свідчать про відсутність єдиної наукової думки щодо визначення понять дискреційних повноважень не тільки органів влади взагалі, а й податкових органів зокрема.

Корупція в Україні набула ознак системного явища, яке поширює свій негативний вплив на всі сфери суспільного життя, дедалі глибше вкорінюючись у повсякденному житті як основний, швидкий та найбільш дієвий протиправний засіб вирішення питань, досягнення певних цілей. Масштаби поширення корупції загрожують національній безпеці України. Це потребує негайного вжиття системних та послідовних заходів, які мають комплексний характер i базуються на єдиній Національній антикорупційній стратегії. За результатами проведених досліджень, у тому числі соціологічних, виявлено, що серед основних причин виникнення $\mathrm{i}$ поширення корупції в Україні - наявність в органів державної влади та осіб, уповноважених на виконання функцій держави або місцевого самоврядування, широкого спектра дискреційних повноважень ${ }^{29}$.

\section{АНОТАЦІЯ}

Актуальність теми дослідження податкової безпеки України в умовах сучасних фінансово-економічних викликів зумовлена реаліями сьогодення, перед якими постала країна. Серед загроз податковій безпеці, що ускладнюють реалізацію національних інтересів України у сфері оподаткування, не останнє місце займають дискреційні повноваження органів влади як чинники корупції. Метою нашого дослідження є огляд проблематики делегування законодавчою владою дискреційних повноважень податковим органам та з'ясування ролі дискреції (розсуду) в податковому законодавстві України. Не менш важливим питанням, що розглядається у статті, $\epsilon$ відповідність наявної в податковому законодавстві України дискреції головному принципу права - принципу

\footnotetext{
${ }^{28}$ Cogan D. The Delicate Balance: Tax, Discretion and the Rule of Law / Chris Evans, Judith Freedman, Richard Krever (eds.). Amsterdam: IBFD, 2011. P. 1.

29 Про Національну антикорупційну стратегію на 2011-2015 роки : Указ Президента України від 21.10.2011 p. № 1001/2011. Офіиійний вісник Украӥни. 2011. № 83. Ст. 3020.
} 
верховенства права. Окремим завданням дослідження $є$ вивчення поглядів науковців стосовно правових обмежень, які можуть запобігти зловживанню дискреційними повноваженнями в податковій царині. Результати проведеного аналізу поглядів науковців стосовно дискреційних повноважень органів влади як чинника корупції, що $є$ загрозою податковій безпеці, свідчать про відсутність єдиної наукової думки щодо визначення понять дискреційних повноважень не тільки органів влади взагалі, а й податкових органів зокрема. Корупція в Україні набула ознак системного явища, яке поширює негативний вплив на всі сфери суспільного життя, дедалі глибше вкорінюючись у повсякденному житті як основний, швидкий та найбільш дієвий протиправний засіб вирішення питань, досягнення певних цілей.

\section{ЛIТЕРАТУРА}

1. Cogan D. The Delicate Balance: Tax, Discretion and the Rule of Law / Chris Evans, Judith Freedman, Richard Krever (eds.). Amsterdam: IBFD, 2011. $368 \mathrm{p}$.

2. Мельничук О.С. Словник іншомовних слів. Київ : Головна редакція української радянської енциклопедії, 1985.968 с.

3. Барабаш Ю.Г. Дискреційні повноваження вищих органів влади: правова природа та умови ефективного застосування. Університетські наукові записки. 2007. № 4. С. 49-54.

4. Грінь А.А. Дискреційні повноваження органів виконавчої влади України та їх реалізація : дис. ... канд. юрид. наук. Київ, 2019. 246 с.

5. Ханова Н.О. Дискреційні повноваження контролюючих органів у сфері оподаткування в Україні : дис. ... канд. юрид. наук. Дніпро, 2019. $195 \mathrm{c.}$

6. Желтобрюх І.Л. Розсуд в податковому правозастосуванні : дис. ... канд. юрид. наук. Ірпінь, 2016. 199 с.

7. Гайдулін О.О. Компаративна інтерпретація понять законодавчого регулювання та правової дискреції: досвід Казахстану та перспективи для України. Часопис Київського університету права. 2018. № 3. С. 26-29.

8. Про затвердження Методології проведення антикорупційної експертизи : Наказ Міністерства юстиції України від 24.04.2017 р. № 1395/5. URL: https://zakon.rada.gov.ua/laws/show/v1395323-17 (дата звернення: 24.05.2020).

9. Білик О.А. Дискреційний характер податкової системи в українському селі першої половини 1920-х рр. Український селянин. 2012. Вип. 13. C. $174-177$. 
10. Бєлкін Л.М. Дискреційні повноваження органів влади як чинник корупції. Боротьба з організованою злочинністю $i$ корупцією (теорія $i$ практика). 2011. Вип. 24. С. 91-100.

11. Золотарьова М.К. Щодо окремих питань застосування дискреційних повноважень посадовими особами органів Державної фіскальної служби України. Форум права. 2015. № 1. С. 123-128.

12. Кобильнік Д.А. Деякі міркування стосовно дискреційних повноважень органів, що здійснюють фінансову діяльність в Україні. Теорія і практика правознавства. 2015. Вип. 2. URL: http://nbuv.gov.ua/ UJRN/tipp_2015_2_20. (дата звернення: 27.05.2020).

13. Костяна О.В. Роль інструментів дискреційного та недискреційного податкового регулювання у стабілізації циклічних коливань економічного розвитку. Економічний аналіз. 2014. Т. 15(2). С. 57-63.

14. Костяна О.В. Аналіз впливу заходів дискреційної податкової політики на бази оподаткування прямих податків. Бізнес Інформ. 2012. № 7. С. 141-145.

15. Кучерявенко М.П. Особливості розсуду в податково-правовому регулюванні. ScienceRise. Juridical Science. 2017. № 1. C. 37-41.

16. Корупційні ризики в діяльності державних службовців: Роз'яснення Міністерства юстиції України від 12.04.2011 p. URL: https://zakon.rada.gov.ua/ laws/show/n0026323-11. (дата звернення: 24.05.2020).

17. Резанов С.А. Дискреційні повноваження як корупційні ризики в діяльності органів державного управління. Право і Безпека. 2014. № 3. C. $88-91$.

18. Антикорупційна експертиза як засіб запобігання корупції : Роз'яснення Міністерства юстиції України від 21.05.2012 p. URL: https://zakon.rada.gov.ua/laws/show/n0018323-12 (дата звернення: 24.05.2020).

19. Методичні рекомендації «Запобігання і протидія корупції в державних органах та органах місцевого самоврядування» : Рекомендації Міністерства юстиції України від 16.10.2013 р. Урядовий кур'єр. 2013. № 208.

20. Деякі питання проведення антикорупційної експертизи : Наказ Міністерства юстиції України від 18.03.2015 p. № 383/5. URL: https://zakon.rada.gov.ua/laws/show/z0303-15\#n7 (дата звернення: 24.05.2020).

21. Про затвердження Методології проведення антикорупційної експертизи : Наказ Міністерства юстиції України від 24.04.2017 р. № 1395/5. URL: https://zakon.rada.gov.ua/laws/show/v1395323-17 (дата звернення: 24.05.2020).

22. Про запобігання корупції : Закон України від 14.10 .2014 p. № 1700-VII. Відомості Верховної Ради Украӥни. 2014. № 49. Ст. 2056. 
23. Про схвалення Стратегії реформування системи державного нагляду (контролю) : Розпорядження Кабінету Міністрів України від 18.12.2017 р. № 1020-р. Офіційний вісник Украӥни. 2018. № 16. Ст. 558.

24. Про Національну антикорупційну стратегію на 2011-2015 роки : Указ Президента України від 21.10.2011 р. № 1001/2011. Офіиійний вісник Украӥни. 2011. № 83. Ст. 3020.

\section{Information about author:} Kolomiiets P. V.,

Ph. D., Associate Professor, Associate Professor of the Department of Law Poltava Institute of Economics and Law of Higher Education Institution "Open International University of Human Development "Ukraine" 6, Monastyrs'ka str., Poltava, 36000, Ukraine 